\title{
Decreased GABA receptor in the cerebral cortex of epileptic rats: effect of Bacopa monnieri and Bacoside- $A$
}

\author{
Jobin Mathew ${ }^{1}$, Savitha Balakrishnan², Sherin Antony ${ }^{2}$, Pretty Mary Abraham² and CS Paulose ${ }^{2^{*}}$
}

\begin{abstract}
Abstact
Background: Gamma amino butyric acid (GABA), the principal inhibitory neurotransmitter in the cerebral cortex, maintains the inhibitory tones that counter balances neuronal excitation. When this balance is perturbed, seizures may ensue.
\end{abstract}

Methods: In the present study, alterations of the general GABA, GABA $A$ and $G_{A B A}$ receptors in the cerebral cortex of the epileptic rat and the therapeutic application of Bacopa monnieri were investigated.

Results: Scatchard analysis of $\left[{ }^{3} \mathrm{H}\right] \mathrm{GABA},\left[{ }^{3} \mathrm{H}\right]$ bicuculline and $\left[{ }^{3} \mathrm{H}\right]$ baclofen in the cerebral cortex of the epileptic rat showed significant decrease in $B_{\max }(P<0.001)$ compared to control. Real Time PCR amplification of GABA receptor subunits such as $G A B A_{A a ́ 1}, G A B A_{A \gamma}, G A B A_{A \delta}, G A B A_{B}$ and $G A D$ where down regulated $(P<0.001)$ in epileptic rats. GABA Aás subunit and Cyclic AMP responsible element binding protein were up regulated. Confocal imaging study confirmed the decreased GABA receptors in epileptic rats. Epileptic rats have deficit in radial arm and $\mathrm{Y}$ maze performance.

Conclusions: Bacopa monnieri and Bacoside-A treatment reverses epilepsy associated changes to near control suggesting that decreased GABA receptors in the cerebral cortex have an important role in epileptic occurrence; Bacopa monnieri and Bacoside-A have therapeutic application in epilepsy management.

Keywords: Epilepsy, Bacopa monnieri, Bacoside-A, Pilocarpine, Carbamazepine

\section{Background}

GABA is formed within GABAergic axon terminals and released into the synapse, where it acts at one of two types of receptor $\mathrm{GABA}_{\mathrm{A}}$ which controls chloride entry into the cell, and $\mathrm{GABA}_{\mathrm{B}}$, which increases potassium conductance, decreases calcium entry, and inhibits the presynaptic release of other neurotransmitters [1,2]. Temporal lobe epilepsy (TLE) is considered the most common epileptic syndrome and it is estimated that approximately $80 \%$ of patients with partial seizures have temporal lobe epilepsy [3]. The effect of pilocarpine treatment, which is characterized by generalized convulsive status epilepticus in rodents, well represents the

\footnotetext{
* Correspondence: cspaulose@cusat.ac.in

${ }^{2}$ Molecular Neurobiology and Cell Biology Unit, Centre for Neuroscience, Department of Biotechnology, Cochin University of Science and Technology, Cochin-682 022, Kerala, India

Full list of author information is available at the end of the article
}

characteristic neuropathological findings in the brain regions of the patients with TLE epilepsy [4]. Imbalance between excitatory and inhibitory synaptic transmission in key brain areas are implicated in the pathophysiology of TLE, in which there is a decrease in the GABA mediated inhibition. TLE seizures reflect excess excitation, which result from local inhibitory circuit dysfunction. The existence of multiple $\mathrm{GABA}_{\mathrm{A}}$ receptor subtypes differing in subunit composition, localization and functional properties underlies their role for finetuning of neuronal circuits and genesis of network oscillations. The differential regulation of $\mathrm{GABA}_{\mathrm{A}}$ receptor subtypes represents a major facet of homeostatic synaptic plasticity and contributes to the excitation/inhibition (E/I) balance under physiological conditions and upon pathological challenges [5]. Glutamate decarboxylase (GAD) is an enzyme that catalyzes the decarboxylation of glutamate to GABA. GAD is the rate limiting enzyme

\section{Biomed Central}


of GABA synthesis and it is used as a marker for GABAergic activity [6]. cAMP response element-binding protein (CREB) is a transcription factor that has been implicated in the activation of protein synthesis required for long-term memory and seizure formation [7]. Findings shows that $\mathrm{GABA}_{\mathrm{B}}$ receptor subunit gene expression in hippocampal neurons is mediated through the CREB by binding to unique cAMP response elements in the alternative promoter regions [8]. Radial arm maze is a means to examine the neural systems that are involved in memory and the influence of pharmacological compounds on memory $[9,10]$. Y-maze used to evaluate the spatial learning by the different animal models of the rats [11]

The potential for antiepileptic drugs to negatively impact cognitive abilities is of significant concern because they are the major therapeutic modality for control of seizures. An increased risk for cognitive deficits has been noted in patients with temporal lobe seizures. Moreover, many of the anticonvulsant drugs presently used for treating epilepsy cannot prevent neurodegeneration but rather contribute towards these cognitive deficits $[12,13]$. The available anti-epileptic drugs are not curative since they mostly treat the symptoms of the disease and render little help to alleviate its cause. This has instilled a renewed interest in traditionally used herbal drugs and formulations, which are safe in prolonged usage for the management of epilepsy.

Bacopa monnieri is well known for its neuropharmacological effects. It is currently recognized as being effective in the treatment of mental illness and epilepsy [14]. Treatments with Bacopa monnieri extract [15] have enhanced learning ability. Cognition-facilitating effect was due to two active saponins, bacosides A and B present in the ethanol extract [16]. These active principles, apart from facilitating learning and memory in normal rats, inhibited the amnesic effects of scopolamine, electroshock and immobilization stress. Crude plant extract or bacosides have also shown anxiolytic effects, antidepressant activity, anticonvulsive action and antioxidant activity [17]. In vitro studies using Bacopa monnieri have been found to inhibit free radical formation and DNA damage in a dose dependent manner [14]. But so far there are very few studies reporting the role of Bacopa monnieri treatment on the functional regulation of GABA receptors. In this study, we investigated the antiepileptic effect of Bacopa monnieri on the GABAergic receptor binding, gene expression in the cerebral cortex and spatial learning and memory in epileptic rats.

\section{Methods}

Chemicals Used in the Study

Biochemicals used in the present study were purchased from Sigma Chemical Co., St. Louis, USA. All other reagents were of analytical grade purchased locally $\left[{ }^{3} \mathrm{H}\right]$ GABA $\left[{ }^{3} \mathrm{H}\right]$ bicuculline and $\left[{ }^{3} \mathrm{H}\right]$ baclofen were purchased from NEN life sciences products Inc., Boston, U.S.A.

\section{Animals}

Adult Wistar rats of 250-300 g body weight purchased from Amrita Institue of Medical Sciences, Cochin and Kerala Agriculture University, were used for all experiments. They were housed in separate cages under 12 hrs light and 12 hrs dark periods and were maintained on standard food pellets and water adlibitum. All animal care and procedures were taken in accordance with the Institutional, National Institute of Health and CPESCA guidelines.

\section{Plant material and Preparation of extract}

Specimen of Bacopa monnieri (L.) Pennel were collected from Cochin University area and were taxonomically identified and authenticated by Mr. K. P. Joseph, Head, Dept. of Botany (retd.), St. Peter's College, Kollenchery and voucher specimens was deposited at a herbarium (No: MNCB3) of Centre for Neuroscience, Cochin University of Science and Technology, Cochin, Kerala, India. Fresh, whole Bacopa monnieri plant were collected and washed. Leaves, roots and stems of Bacopa monnieri plant were cut into small pieces and dried in shade. $100 \mathrm{~g}$ fresh plant dried in shade yielded approximately $15 \mathrm{~g}$ powder. Homogenate was extracted at required concentration $(300 \mathrm{mg}$ fresh plant $/ \mathrm{kg}$ body weight) by dissolving $450 \mathrm{mg}$ of dried powder in $80 \mathrm{ml}$ distilled water and used for the study $[18,19]$.

\section{Induction of Epilepsy in adult rats}

Adult male Wistar rats, weighing 250 to 300 g, were housed for 1 to 2 weeks before experiments were performed. Epilepsy was induced by injecting rats with pilocarpine ( $350 \mathrm{mg} / \mathrm{kg}$ body weight i.p.), preceded by 30 min with atropine $(1 \mathrm{mg} / \mathrm{kg}$ body weight i.p.) to reduce peripheral pilocarpine effects. Within 20 to $40 \mathrm{~min}$ after the pilocarpine injection, essentially all the animals developed status epilepticus (SE). Control animals were given saline injection. Behavioural observation continued for $5 \mathrm{hrs}$ after pilocarpine injection. SE was allowed to continue for $1 \mathrm{hr}$ and then control and experimental animals were treated with diazepam $(4 \mathrm{mg} / \mathrm{kg}$ body weight i.p.). Animals recovered from this initial treatment within 2 to 3 days and were observed for the next 3 weeks. 24 days after pilocarpine treatment, the rats were continuously video monitored for $72 \mathrm{hrs}$. The behaviour and seizures were captured with a CCD camera and a Pinnacle PCTV capturing software card. One trained technician, blind to all experimental conditions, viewed all videos. Seizure activity was rated according to Racine Scale [20]. Seizures were assessed by viewing 
behavioural postures (i.e. lordosis, straight tail, jumping/ running, forelimb clonus and/or rearing) during observation of the videos. Experimental rats which showed recurrent seizures were used for the further experiments. Experimental rats were divided into five groups: 1) Control (C), 2) Epileptic (E), 3) Epileptic rats treated with Bacopa monnieri $(\mathrm{E}+\mathrm{B})$, 4) Epileptic rats treated with bacoside-A $(E+D)$, 5) Epileptic rats treated with carbamazepine $(\mathrm{E}+\mathrm{C})$. Bacopa monnieri treated rats were given extract of Bacopa monnieri orally in the dosage $300 \mathrm{mg} / \mathrm{kg}$ body weight/day for 15 days. Carbamazepine- a standard drug used for the treatment of epilepsy was given orally in the dosage $150 \mathrm{mg} / \mathrm{kg}$ body weight/day for 15 days. Bacoside-A was given orally in the dosage $150 \mathrm{mg} / \mathrm{kg}$ body weight/day for 15 days. After the treatment the rats were sacrificed and the tissues were stored in $-80^{\circ} \mathrm{C}$.

\section{Protein Determination}

Protein was measured by the method of Lowry et al [21] using bovine serum albumin as standard. The intensity of the purple blue colour formed was proportional to the amount of protein, which was read in a spectrophotometer at $660 \mathrm{~nm}$.

\section{GABA Receptor Binding Assay}

$\left[{ }^{3} \mathrm{H}\right] \mathrm{GABA}$ binding to GABA, $\left[{ }^{3} \mathrm{H}\right]$ bicuculline to $\mathrm{GABA}_{\mathrm{A}}$ and $\left[{ }^{3} \mathrm{H}\right]$ baclofen binding to $\mathrm{GABA}_{B}$ receptors were assayed in triton $\mathrm{x}-100$ treated synaptic membranes according to the procedure of Kurioka et al [22]. Crude synaptic membrane was prepared using sodium-free 10 $\mathrm{mM}$ Tris buffer $\left(\mathrm{P}^{\mathrm{H}} 7.4\right)$. Each assay tube contained a protein concentration of $100 \mathrm{mg}$. In saturation binding experiments, 5-40 nM of $\left[{ }^{3} \mathrm{H}\right]$ GABA incubated with and without excess of unlabelled GABA $(100 \mu \mathrm{M})$. The incubation was continued for $20 \mathrm{~min}$ at $40^{\circ} \mathrm{C}$ and terminated by centrifugation at $35000 \mathrm{xg}$ for $20 \mathrm{~min}$. [ $\left.{ }^{3} \mathrm{H}\right]$ GABA in the pellet was determined by liquid scintillation spectrometry. Specific binding was determined by subtracting non-specific binding from the total binding.

\section{Real-Time Polymerase Chain Reaction}

Total RNA was isolated from the cerebral cortex of control and experimental rats using Tri reagent. RNA was reverse transcribed using ABI PRISM cDNA Archive kit. $20 \mu \mathrm{l}$ of the reaction mixture contained $0.2 \mu \mathrm{g}$ total RNA, 10X RT buffer, 25X dNTP mixture, 10X Random primers, MultiScribe RT $(50 \mathrm{U} / \mu \mathrm{l})$ and RNAase free water. The reactions were carried out at $25^{\circ} \mathrm{C}$ for 10 minutes and $37^{\circ} \mathrm{C}$ for 2 hours using an Eppendorf Personal Cycler. Real-Time PCR assays were performed using specific primer and fluorescently labeled Taq probe in an ABI 7300 Real-Time PCR instrument (Applied Biosystems). The TaqMan reaction mixture of
$20 \mu \mathrm{l}$ contained $25 \mathrm{ng}$ of total RNA-derived cDNAs, 200 $\mathrm{nM}$ each of the forward primer, reverse primer and TaqMan probe for specific gene, endogenous control, $\beta$ actin and $12.5 \mu \mathrm{l}$ of TaqMan 2X Universal PCR Mastermix. The thermocycling profile conditions used were: $50^{\circ} \mathrm{C}$ - 2 minutes - Activation; $95^{\circ} \mathrm{C}$ - 10 minutes Initial Denaturation; followed by 40 cycles of $95^{\circ} \mathrm{C}-15$ seconds - Denaturation and $60^{\circ} \mathrm{C}-1$ minute - Annealing. The $\Delta \Delta \mathrm{CT}$ method of relative quantification was used to determine the fold change in expression. This was done by first normalizing the resulting threshold cycle (CT) values of the target mRNAs to the CT values of the internal control $\beta$-actin in the same samples $(\Delta \mathrm{CT}=$ $\left.\mathrm{CT}_{\text {Target }}-\mathrm{CT}_{\beta \text {-actin }}\right)$. It was further normalized with the control $(\Delta \Delta \mathrm{CT}=\Delta \mathrm{CT}-\mathrm{CT}$ Control $)$. The fold change in expression was then obtained as $\left(2^{-\Delta \Delta C T}\right)$ and expressed as $\log 2^{-\Delta \Delta C T}$.

The sequences of the probe were

GABA $_{\text {Á́1 } 1}$ :- ATTTGGGAGCTATGCTTATACAAGA

GABA $_{\text {Á́ } 5}$ :- CAGCACCAGCACAGGTGAATATACA

GABA $_{\mathrm{A \gamma} 3}$ :- GCATGCTCGGTCCAGGAGGGTGGAA

GABA $_{\mathrm{A} \delta}$ :- CCGCACCATGGCGCCAGAGCAATGA

GAD65:- AGTCATTACAAATCT TGCCC

The sequences of the primers were

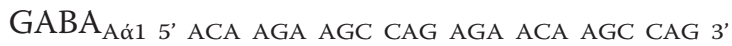

5' GAG GTC TAC TGG TAA GCT CTA CCA 3'

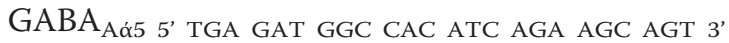

5' TCA TGG GAG GCT GGA GTT TAG TTC 3'

GABA $_{\text {A } \gamma 3}$ 5' CAG AGA CAG GAA GCT GAA AAG CAA 3'

5' CGA AGT GAT TAT ATT GGA CTA AGC 3'

GABA $_{\text {A } \delta}$ 5' TGT GAG CAA CCG GAA ACC AAG CAA-3'

5' CGT GTG ATT CAG CGA ATA AGA CCC-3'

GAD65 5'GCCCAGGCTCATCGCATTCA-3'

5'AGTCATTACAAATCT TGCCC-3'

\section{Linear regression analysis for Scatchard plots}

The data were analysed according to Scatchard [23]. The specific binding was determined by subtracting non-specific binding from the total. The binding parameters, maximal binding $\left(\mathrm{B}_{\max }\right)$ and equilibrium dissociation constant $\left(\mathrm{K}_{\mathrm{d}}\right)$, were derived by linear regression analysis by plotting the specific binding of the radioligand on $\mathrm{X}$-axis and bound/free on $\mathrm{Y}$-axis. The maximal binding is a measure of the total number of receptors 
present in the tissue and the equilibrium dissociation constant is the measure of the affinity of the receptors for the radioligand. $K_{d}$ is inversely related to receptor affinity.

\section{Radial Maze Test}

Radial maze behavioral testing was conducted under normal room lighting and utilized an eight armed radial maze elevated $100 \mathrm{~cm}$ from the floor. Each arm of the maze $(11.5 \mathrm{~cm}$ wide) extended $68.5 \mathrm{~cm}$ from an octagonally shaped central platform (40 cm across). Black Plexiglas walls $(11.5 \mathrm{~cm}$ high) were present only for the first $20 \mathrm{~cm}$ of each arm to prevent the rat crossing from one to another without returning to the central platform. Circular food wells $(1.3 \mathrm{~cm}$ deep, $3.2 \mathrm{~cm}$ diameter were located $2.5 \mathrm{~cm}$ from the end of each arm. The maze was centered in an enclosed room where lighting and spatial cues (e.g., posters, door, and boxes) remained constant throughout the course of the experiment. Arms were baited by placing one raisin in each food well.

Rats were placed on the maze 3 days prior to the start of formal acquisition testing in order to habituate them to the apparatus. On the first day of habituation, 4 food pellets were scattered along the length of each arm. The rats were then systematically confined to each arm for 1 min to ensure their exposure to the entire maze. On the second day of habituation, the previous day's procedure was repeated except that the animals were not confined to each arm following $5 \mathrm{~min}$ of exploration. On the third day, one food pellet was placed in the food well at the end of each arm and a second was placed halfway down each arm. Once the rats were habituated to the maze, testing began. Trials began by placing a single rat in the center of the maze facing away from the experimenter. The trial ended when the rat had obtained all 4 pellets or $5 \mathrm{~min}$ had elapsed, whichever occurred first. Rats were run until they achieved criterion performance for task acquisition. Criterion was attained when the rat collected 3 out of the 4 food pellets within their first 4 arm entries within a trial (while still completing the trial) with this level of performance being maintained for 5 consecutive criterion performance. The number of trials up to and including the last of these 5 criterion performance formed the "number of trials to criterion" measure. Experimental subjects were tested under blind conditions. The time of testing was consistent from day to day for each subject but testing of the various treatment groups was distributed randomly throughout the day.

\section{Y-Maze Test}

The Y-maze was made of grey wood, covered with black paper, and consisted of three arms with an angle of $120^{\circ}$ between each of the arms. Each arm was $8 \mathrm{~cm}$ width $\times 30 \mathrm{~cm}$ length $\times 15 \mathrm{~cm}$ height. The three identical arms were randomly designated: Start arm, in which the mouse started to explore (always open); Novel arm, which was blocked at the 1st trial, but open at the 2nd trial; and the other arm (always open). The maze was placed in a separate room with enough light. The floor of the maze was covered with sawdust, which was mixed after each individual trial in order to eliminate olfactory stimuli. Visual cues were placed on the walls of the maze.

The Y-maze test consisted of two trials separated by an inter-trial interval (ITI). The first trial (training) was 10 min duration and allowed the mouse to explore only two arms (start arm and the other arm) of the maze, with the third arm (novel arm) blocked. After a $1 \mathrm{~h}$ ITI [24], the second trial (retention) was conducted, during which all three arms were accessible and novelty vs. familiarity was analyzed through comparing behavior in all three arms. For the second trial, the mouse was placed back in the maze in the same starting arm, with free access to all three arms for $5 \mathrm{~min}$. The time spent in each arm were analyzed data were expressed as percentage of performance in all three arms during the 5minutes of test [25].

\section{Confocal imaging}

Control and experimental rats were deeply anesthetized with ether. The rat was transcardially perfused with PBS (pH- 7.4) followed by 4\% paraformaldehyde in PBS [26]. After perfusion the brains were dissected and immersion fixed in 4\% paraformaldehyde for $1 \mathrm{hr}$ and then equilibrated with $30 \%$ sucrose solution in $0.1 \mathrm{M}$ PBS. $40 \mu \mathrm{m}$ sections were cut using Cryostat (Leica, CM1510 S). The sections were treated with PBST (PBS in 0.05\% Triton $\mathrm{X}-100)$ for $20 \mathrm{~min}$. Brain slices were incubated overnight at $4^{\circ} \mathrm{C}$ with rat primary antibody for $\mathrm{GABA}_{\mathrm{A \alpha}} 1$. The brain slices were then rinsed with PBST and then incubated with Rhodamine coated secondary antibody. The sections were observed and photographed using confocal imaging system (Leica SP 5).

\section{Results}

Scatchard analysis of $\left[{ }^{3} \mathrm{H}\right] \mathrm{GABA}$ binding against GABA in the cerebral cortex of Control, Epileptic, Epileptic + Bacopa monnieri, Epileptic + Bacoside A, and Epileptic + Carbamazepine treated rats

Scatchard analysis of $\left[{ }^{3} \mathrm{H}\right] \mathrm{GABA}$ against GABA in the cerebral cortex showed a significant decrease $(\mathrm{P}<0.001)$ in the $B_{\text {max }}$ of epileptic rats compared to controls. $K_{d}$ showed significant decrease $(\mathrm{P}<0.05)$ in the epileptic group compared to control. Treatment using Bacopa monnieri, Bacocide-A and Carbamazepine reversed the $\mathrm{B}_{\max }$ to near control (Table 1). 
Table 1 Scatchard analysis of [3H]GABA binding against GABA in the cerebral cortex of control and experimental rats

\begin{tabular}{lll}
\hline Group & $\mathbf{B}_{\max }($ fmoles/mg ptn) & $\mathbf{K}_{\mathbf{d}}(\mathbf{n M})$ \\
\hline$C$ & $112.3 \pm 6.3$ & $2.6 \pm 0.3$ \\
\hline$E$ & $44.0 \pm 3.5^{* * *}$ & $1.5 \pm 0.1^{* *}$ \\
\hline$E+B$ & $89.8 \pm 5.6^{@ @ ~}$ & $2.3 \pm 0.2$ \\
\hline$E+D$ & $93.2 \pm 4.7^{@ @ ~}$ & $2.2 \pm 02$ \\
\hline$E+C$ & $80.7 \pm 5.2^{@ @}$ & $2.1 \pm 0.1$
\end{tabular}

Values are mean \pm SEM of 4-6 separate experiments. Each group consist of 68 rats ${ }^{* *} \mathrm{p}<0.01,{ }^{* * *} \mathrm{p}<0.001$ when compared to control, @@ $<0.01$, @@@ $<0.001$ when compared to epileptic group. C-Control, E- Epileptic, E+BEpileptic rats treated with Bacopa monnieri, E+D- Epileptic rats treated with Bacoside $\mathrm{A}$ and $\mathrm{E}+\mathrm{C}$ - Epileptic rats treated with Carbamazepine.

Scatchard analysis of $\left[{ }^{3} \mathrm{H}\right]$ bicuculline against Bicuculline and $\left[{ }^{3} \mathrm{H}\right]$ baclofen against baclofen in the cerebral cortex of Control, Epileptic, Epileptic + Bacopa monnieri, Epileptic + Bacoside A and Epileptic + Carbamazepine, treated rats

Scatchard analysis of $\left[{ }^{3} \mathrm{H}\right]$ bicuculline against bicuculline and $\left[{ }^{3} \mathrm{H}\right]$ baclofen against baclofen in the cerebral cortex showed a significant decrease $(\mathrm{P}<0.001)$ in the $\mathrm{B}_{\max }$ of epileptic rats compared to controls. $\mathrm{K}_{\mathrm{d}}$ showed significant decrease $(P<0.05)$ in epileptic group compared to control. Treatment using Bacopa monnieri, Bacocide-A and Carbamazepine reversed the $B_{\max }$ to near control (Tables 2 and 3).

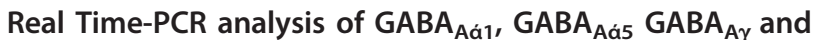
$G A B A_{A \delta}$, receptor subunit mRNA in the cerebral cortex of Control, Epileptic, Epileptic + Bacopa monnier , Epileptic + Bacoside $A$ and Epileptic + Carbamazepine treated rats Gene expression of $\mathrm{GABA}_{\mathrm{A} \alpha \dot{\alpha} 1}, \mathrm{GABA}_{\mathrm{A} \gamma}$ and $\mathrm{GABA}_{\mathrm{A} \delta}$, where showed significant down regulation $(p<0.001)$ in the cerebral cortex of the epileptic rats compared to the control. Gene expression of $\mathrm{GABA}_{\mathrm{A} \dot{\alpha} 5}$ receptor subunit showed significant up regulation compared to the control. Treatment using Bacopa monnieri, Bacocide-A and

Table 2 Scatchard analysis of $\left[{ }^{3} \mathrm{H}\right]$ bicuculline binding against bicuculline in the cerebral cortex of control and experimental rats

\begin{tabular}{lll}
\hline Group & $\mathbf{B}_{\max }$ (fmoles/mg ptn) & $\mathrm{K}_{\mathbf{d}}(\mathbf{n M})$ \\
\hline$C$ & $85.4 \pm 4.5$ & $1.7 \pm 0.3$ \\
\hline$E$ & $37.9 \pm 3.9^{* * *}$ & $0.9 \pm 0.1^{* *}$ \\
\hline$E+B$ & $75.0 \pm 5.3^{@ @ @ ~}$ & $1.2 \pm 0.3$ \\
\hline$E+D$ & $80.1 \pm 6.1^{@ @ @ ~}$ & $1.39 \pm 0.1$ \\
\hline$E+C$ & $76.5 \pm 4.7^{@ @ @ ~}$ & $1.38 \pm 0.2$
\end{tabular}

Values are mean \pm SEM of 4-6 separate experiments. Each group consist of 68 rats ${ }^{* *} \mathrm{p}<0.01,{ }^{* * *} \mathrm{p}<0.001$ when compared to control, @@ $<0.01$, @@@ $<0.001$ when compared to epileptic group. C-Control, E- Epileptic, E+BEpileptic rats treated with Bacopa monnieri, E+D- Epileptic rats treated with Bacoside $\mathrm{A}$ and $\mathrm{E}+\mathrm{C}$ - Epileptic rats treated with Carbamazepine.
Table 3 Scatchard analysis of $\left[{ }^{3} \mathrm{H}\right]$ baclofen binding against Baclofen in the cerebral cortex of control and experimental rats

\begin{tabular}{|c|c|c|}
\hline Group & $B_{\max }($ fmoles/mg ptn) & $\mathrm{K}_{\mathrm{d}}(\mathrm{nM})$ \\
\hline C & $124.3 \pm 8.5$ & $1.8 \pm 0.2$ \\
\hline E & $91.9 \pm 6.9^{* * *}$ & $1.2 \pm 0.1^{* *}$ \\
\hline$E+B$ & $115.2 \pm 7.3^{@ @ @ ~}$ & $1.6 \pm 0.3$ \\
\hline$E+D$ & $111.7 \pm 5.1^{@ @ @ ~}$ & $1.3 \pm 0.1$ \\
\hline$\overline{E+C}$ & $107.1 \pm 7.7^{@ @ @ ~}$ & $1.4 \pm 0.2$ \\
\hline
\end{tabular}

Values are mean \pm SEM of 4-6 separate experiments. Each group consist of 6 8 rats ${ }^{* *} \mathrm{p}<0.01,{ }^{* * *} \mathrm{p}<0.001$ when compared to control, @@ $<0.01$, @@@ $<0.001$ when compared to epileptic group. C- Control, E- Epileptic, E+BEpileptic rats treated with Bacopa monnieri, E+D- Epileptic rats treated with Bacoside $\mathrm{A}$ and $\mathrm{E}+\mathrm{C}$ - Epileptic rats treated with Carbamazepine.

Carbamazepine reversed the changes to near control (Figures 1, 2, 3 and 4).

Real Time-PCR analysis of GABA $A_{B}$, GAD65 and CREB mRNA in the cerebral cortex of Control, Epileptic, Epileptic + Bacopa monnieri, Epileptic + Bacoside A and Epileptic + Carbamazepine treated Epileptic rats Gene expression of CREB $m R N A$ showed significant up regulation $(\mathrm{p}<0.001)$ in the cerebral cortex of the epileptic rats compared to the control. $\mathrm{GABA}_{\mathrm{B}}$, and GAD65 mRNA were significantly down regulated compared to the control. Treatment using Bacopa monnieri, Bacoside- $\mathrm{A}$ and Carbamazepine were reversed the changes to near control (Figures 5, 6 and 7).

\section{Eight-Arm Radial Maze Performance}

There was significant increase $(\mathrm{p}<0.001)$ in the number of trials required to achieve five consecutive criterion performances in the epileptic rats compared to control. Treatment using Bacopa monnieri and Bacoside-A reversed this change to near control (Figure 8).

\section{$Y$-Maze Performance}

Time spent in the novel arm was decreed significantly ( $\mathrm{p}<0.001)$ in the epileptic group compared to control. Bacopa monnieri and Bacocide-A treated epileptic rats were showed improved performance (Figure 9).

$\mathrm{GABA}_{\mathrm{A \alpha} 1}$ receptor antibody staining in the Hippocampus of Control, Epileptic, Epileptic + Bacopa monnieri, Epileptic + Bacoside A and Epileptic + Carbamazepine treated Epileptic rats

$\mathrm{GABA}_{\mathrm{A} \alpha 1}$ receptor subunit antibody staining in the hippocampus showed a significant decrease $(\mathrm{p}<0.01)$ in the $\mathrm{GABA}_{\mathrm{A} \alpha 1}$ receptor subunit in epileptic rat compared to control. Bacopa monnieri, Bacoside-A and Carbamazepine treated epileptic rats showed a significant reversal $(\mathrm{p}<0.05)$ of the decrease in $\mathrm{GABA}_{\mathrm{A} \alpha 1}$ receptor subunit staining in the hippocampus compared to epileptic rats (Figure 10). 


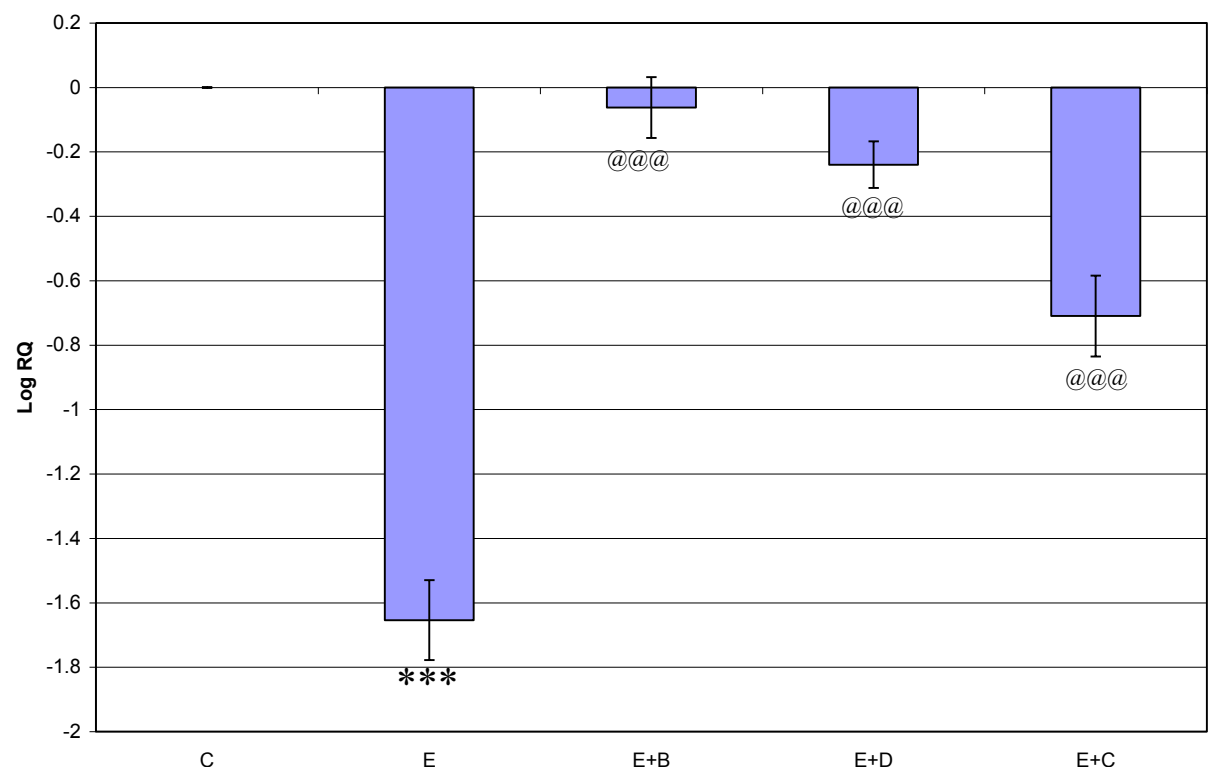

Figure 1 Representative graph showing Real-Time amplification of GABA ${ }_{A \alpha 1}$ receptor subunit $m$ RNA from the Control and experimental rats. The $\triangle \triangle C T$ method of relative quantification was used to determine the fold change in expression. Values are mean \pm S.D of 4-6 separate experiments. C-Control, E- Epileptic, E+B- Epileptic + Bacopa monnieri, E+D- Epileptic + Bacoside-A, E+C- Epileptic + carbamazepine treated rats. ${ }^{* * *} \mathrm{p}<0.001$ when compared to control, ${ }^{@} @ \mathrm{p}<0.001$ when compared to epileptic group.

\section{Discussion}

In this study, we focused on the involvement of cortical GABA receptors in temporal lobe epilepsy, associated mood disorders, spatial learning and memory deficit in epileptic rats. TLE is a common end result of braindamaging insults with very different etiologies and initial pathologies, such as genetic malformation, head trauma, stroke, infection or status epilepticus [27]. Although

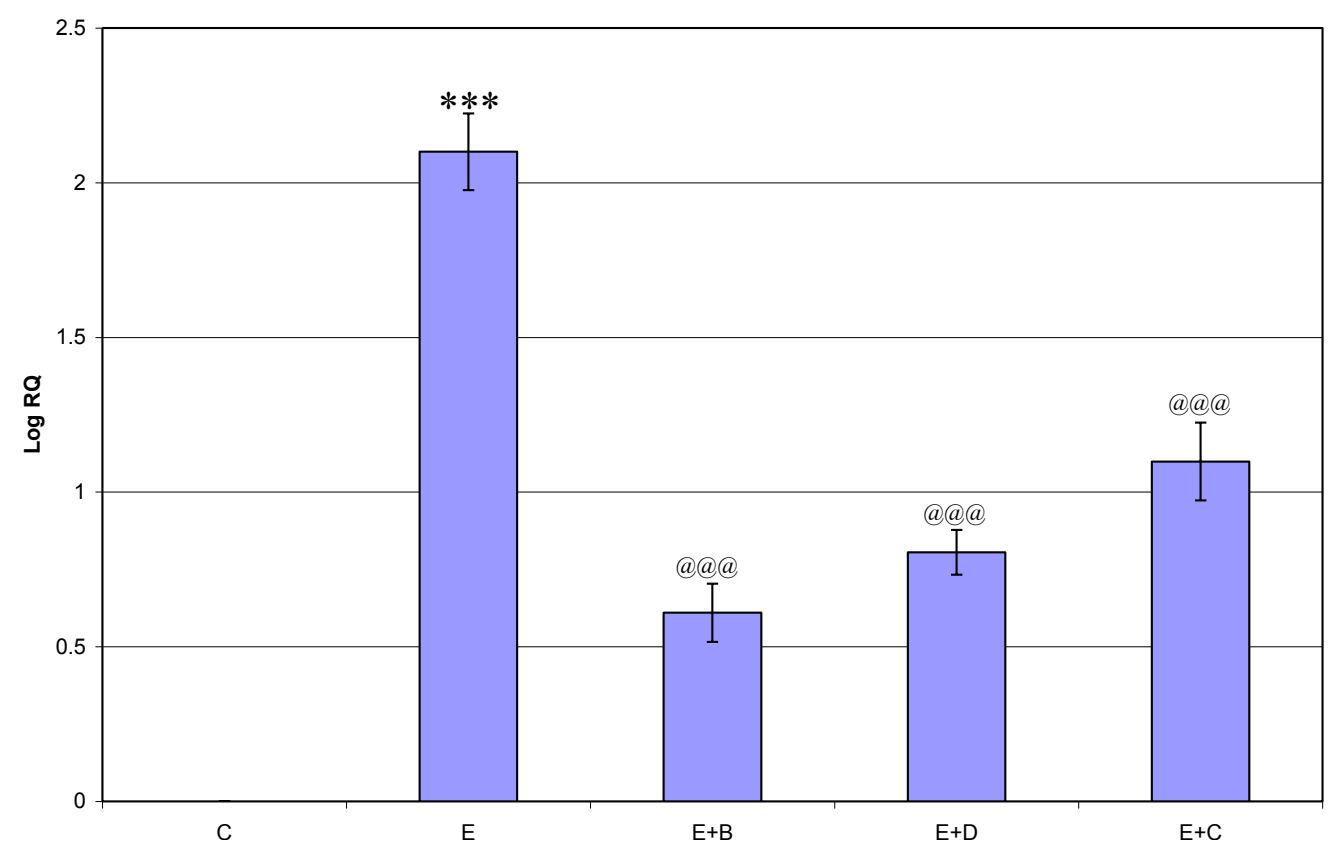

Figure 2 Representative graph showing Real-Time amplification of $\mathrm{GABA}_{\mathrm{A} \alpha 5}$ receptor subunit $\mathrm{mRNA}$ from the Control and experimental rats. The $\triangle \triangle C T$ method of relative quantification was used to determine the fold change in expression. Values are mean \pm S.D of 4-6 separate experiments. C-Control, E- Epileptic, E+B- Epileptic + Bacopa monnieri, E+D- Epileptic + Bacoside-A, E+C- Epileptic + carbamazepine treated rats. ${ }^{* * *} \mathrm{p}<0.001$ when compared to control, ${ }^{@ @ @ ~} \mathrm{p}<0.001$ when compared to epileptic group. 


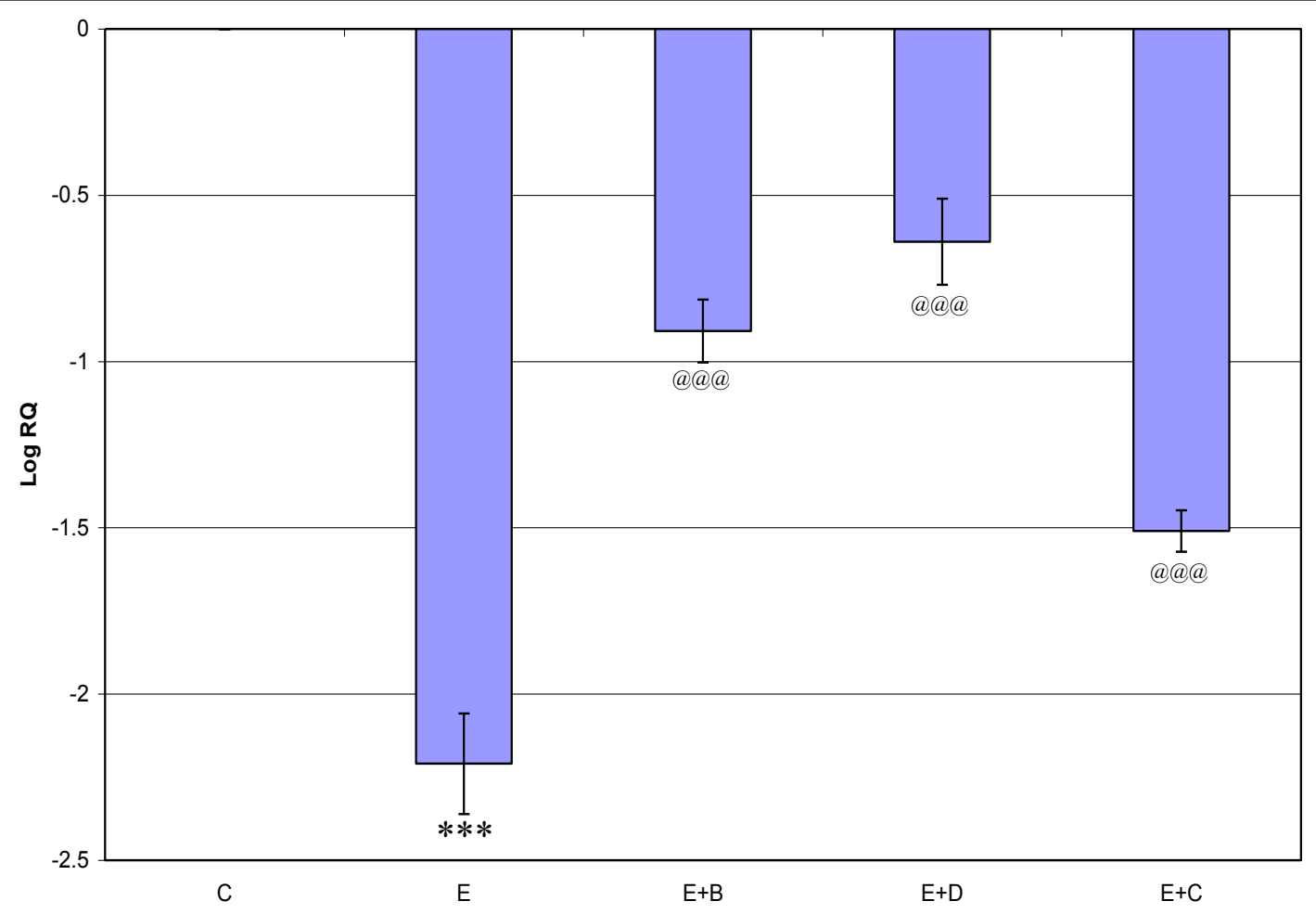

Figure 3 Representative graph showing Real-Time amplification of GABA ${ }_{\text {A } 5}$ receptor subunit mRNA from the Control and experimental rats. The $\triangle \triangle C T$ method of relative quantification was used to determine the fold change in expression. Values are mean \pm S.D of 4-6 separate experiments. C- Control, E- Epileptic, E+B- Epileptic + Bacopa monnieri, E+D- Epileptic + Bacoside-A, E+C- Epileptic + carbamazepine treated rats. ${ }^{* *} \mathrm{p}<0.001$ when compared to control, $@ @ @ p<0.001$ when compared to epileptic group.

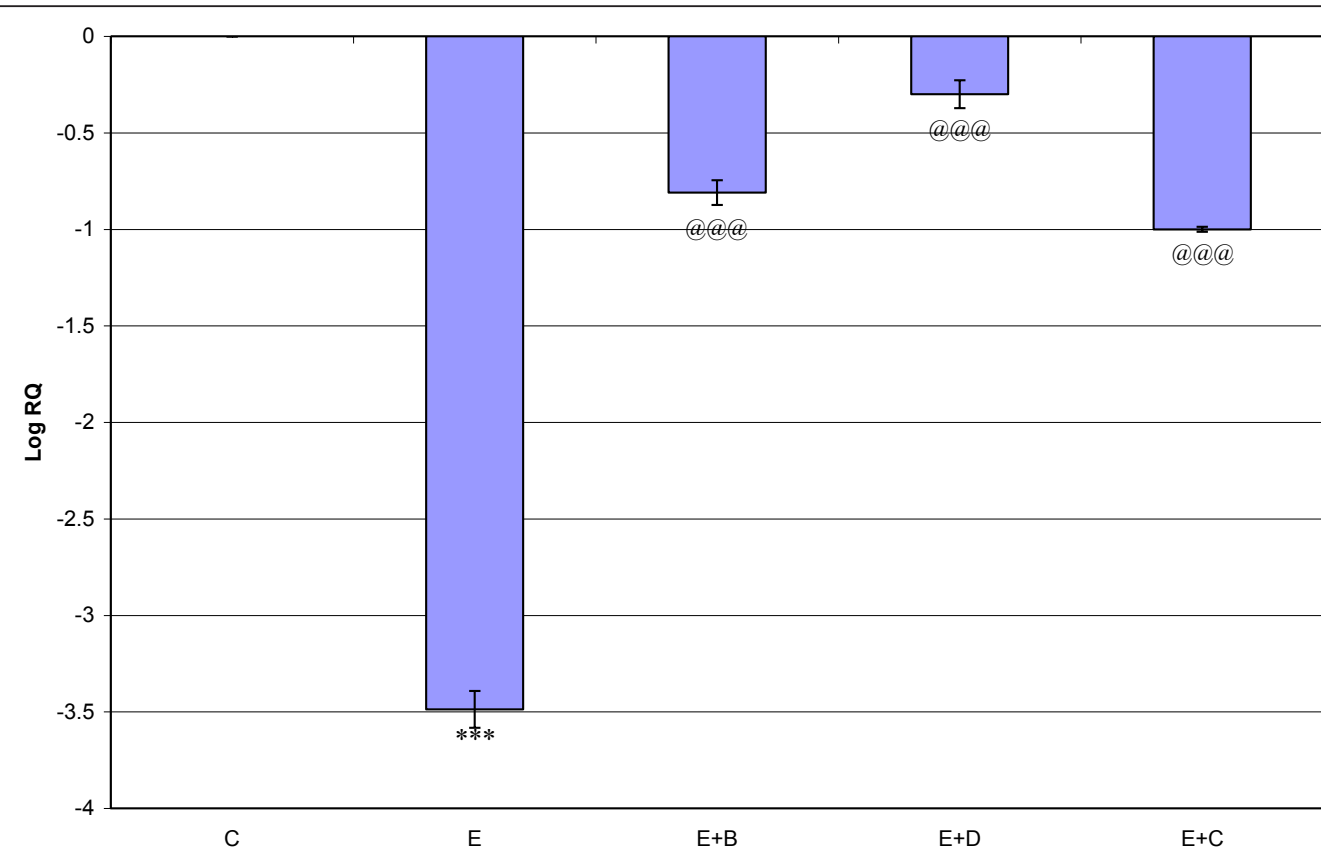

Figure 4 Representative graph showing Real-Time amplification of GABA A $\delta 5_{5}$ receptor subunit mRNA from the Control and experimental rats. The $\triangle \triangle C T$ method of relative quantification was used to determine the fold change in expression. Values are mean $\pm S . D$ of 4-6 separate experiments. C- Control, E- Epileptic, E+B- Epileptic + Bacopa monnieri, E+D- Epileptic + Bacoside-A, E+C- Epileptic + carbamazepine treated rats. ${ }^{* * *} p<0.001$ when compared to control, @@@ $p<0.001$ when compared to epileptic group. 


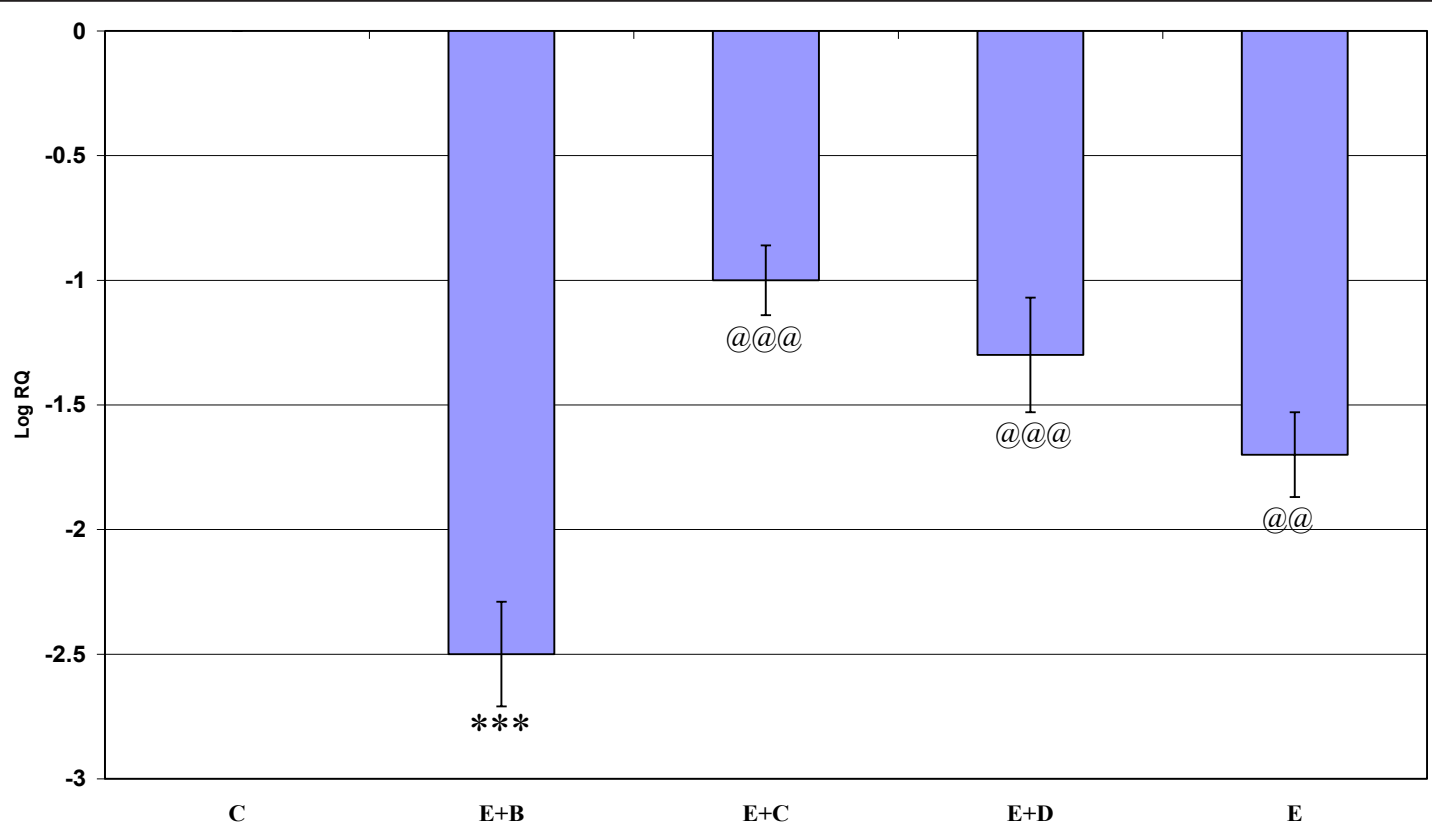

Figure 5 Representative graph showing Real-Time amplification of $\mathrm{GABA}_{\mathrm{B}}$ receptor mRNA from the Control and experimental rats. The $\triangle \triangle C T$ method of relative quantification was used to determine the fold change in expression. Values are mean \pm S.D of 4-6 separate experiments. C-Control, E- Epileptic, E+B- Epileptic + Bacopa monnieri, E+D- Epileptic + Bacoside-A, E+C-Epileptic + carbamazepine treated rats. ${ }^{* * *} \mathrm{p}<0.001$ when compared to control, $@ @ \mathrm{p}<0.001$ when compared to epileptic group.

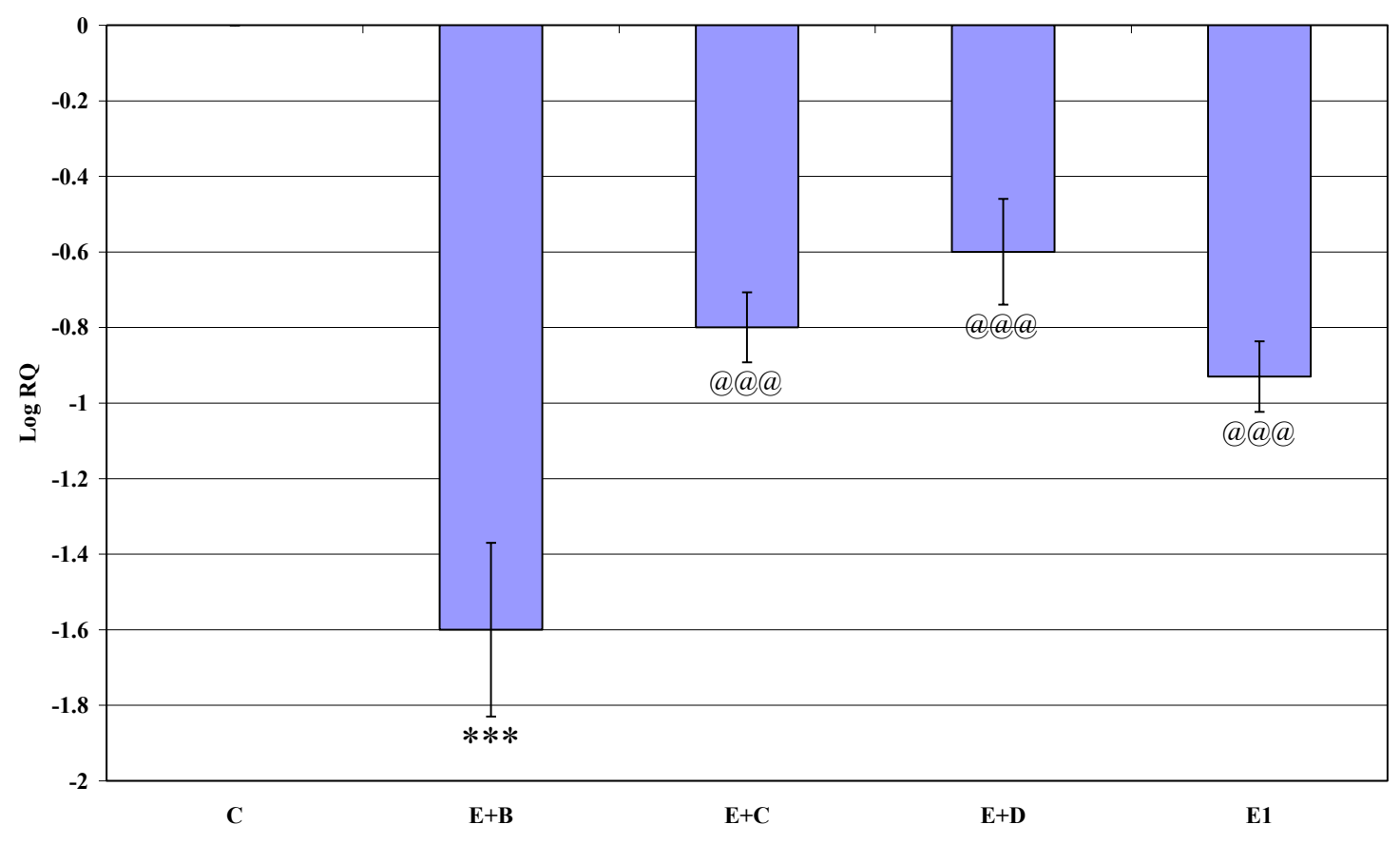

Figure 6 Representative graph showing Real-Time amplification of GAD mRNA from the Control and experimental rats. The $\triangle \triangle C T$ method of relative quantification was used to determine the fold change in expression. Values are mean \pm S.D of 4-6 separate experiments. CControl, E- Epileptic, E+B- Epileptic+ Bacopa monnieri, E+D- Epileptic + Bacoside-A, E+C- Epileptic + carbamazepine treated rats. ${ }^{* *} \mathrm{p}<0.001$ when compared to control, $@^{@} \mathrm{p}<0.001$ when compared to epileptic group. 


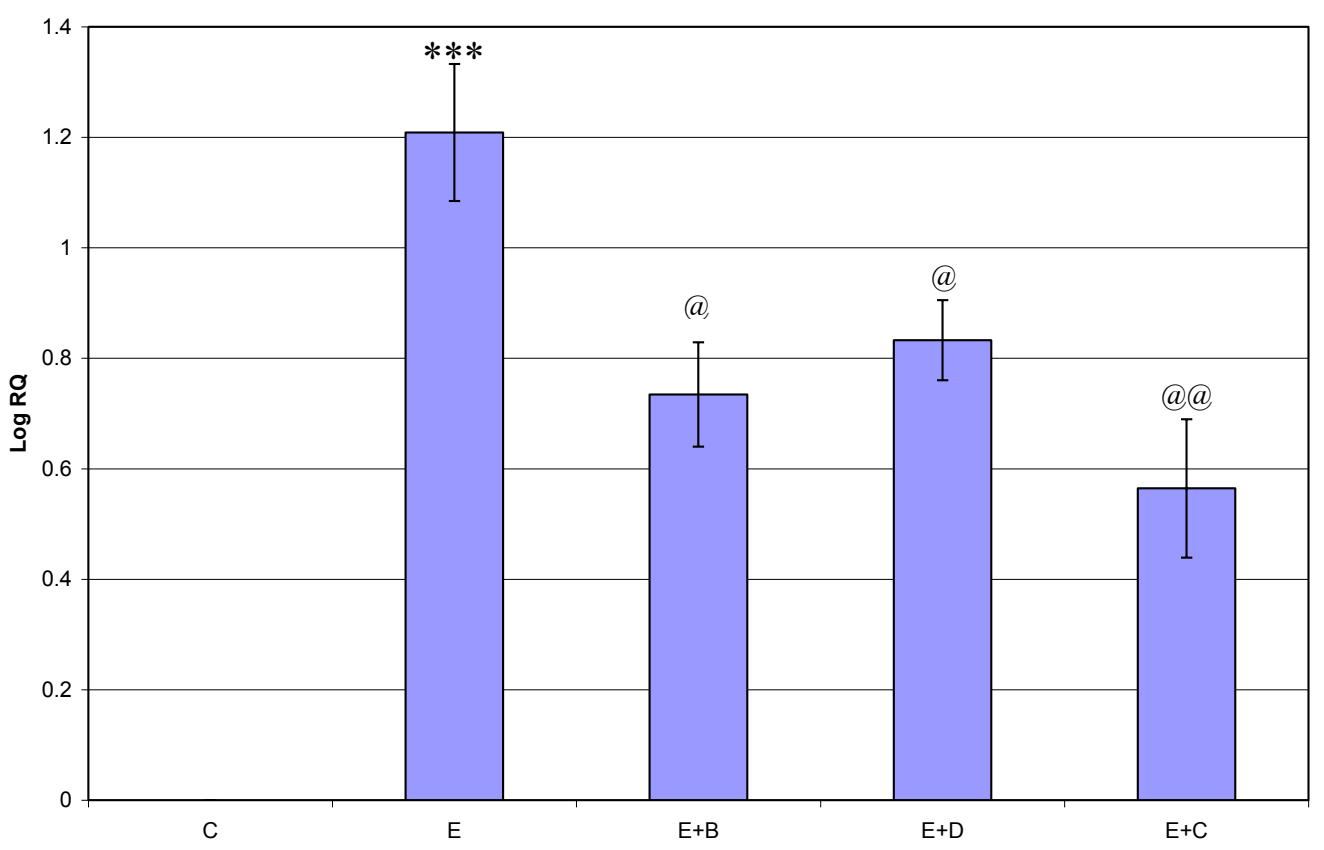

Figure 7 Representative graph showing Real-Time amplification of CREB mRNA from the Control and experimental rats. The $\triangle \triangle C T$ method of relative quantification was used to determine the fold change in expression. Values are mean \pm S.D of 4-6 separate experiments. CControl, E- Epileptic, E+B- Epileptic+ Bacopa monnieri, E+D- Epileptic + Bacoside-A, E+C-Epileptic + carbamazepine treated rats. ${ }^{* * *} p<0.001$ when compared to control, $@_{\mathrm{p}}^{\mathrm{p}}<0.01,{ }^{@} \mathrm{p}<0.05$ when compared to epileptic group.

there are various reports of the anticonvulsant and neuroprotective properties of Bacopa monnieri and its active component Bacoside-A, little effort has been extended to understand their pharmacological action on the GABA receptors in the cerebral cortex of the epileptic rats. GABA is the major inhibitory neurotransmitter in the central nervous system [28,29]. It exerts an inhibitory action in all forebrain structures and plays a role in the physiopathogenesis of epilepsy [30]. GABA $_{\mathrm{A}}$ receptor binding influences the early portion of the

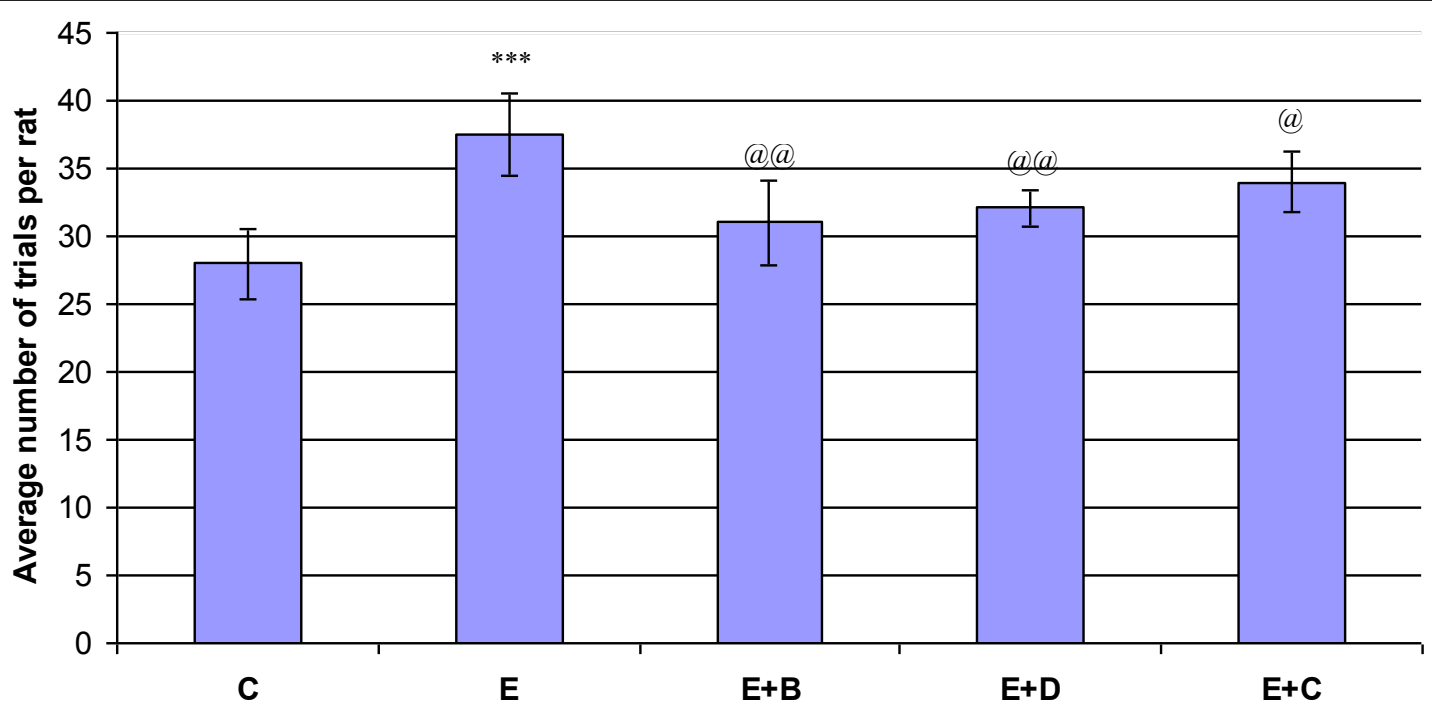

Figure 8 Representative graph showing radial arm maze performance of control and experimental rats epileptic rats required more daily trials to achieve three, four, and five consecutive criterion performances. Criterion performance was defined as consumption of the bait in the four baited arms of the radial maze during no more than five entries. There was no significant difference in the average number of trials required by kindled and control rats to achieve the initial criterion performance. C- Control, E- Epileptic, E+B- Epileptic + Bacopa monnieri, E + D- Epileptic + Bacoside-A, E+C- Epileptic + carbamazepine treated rats. 


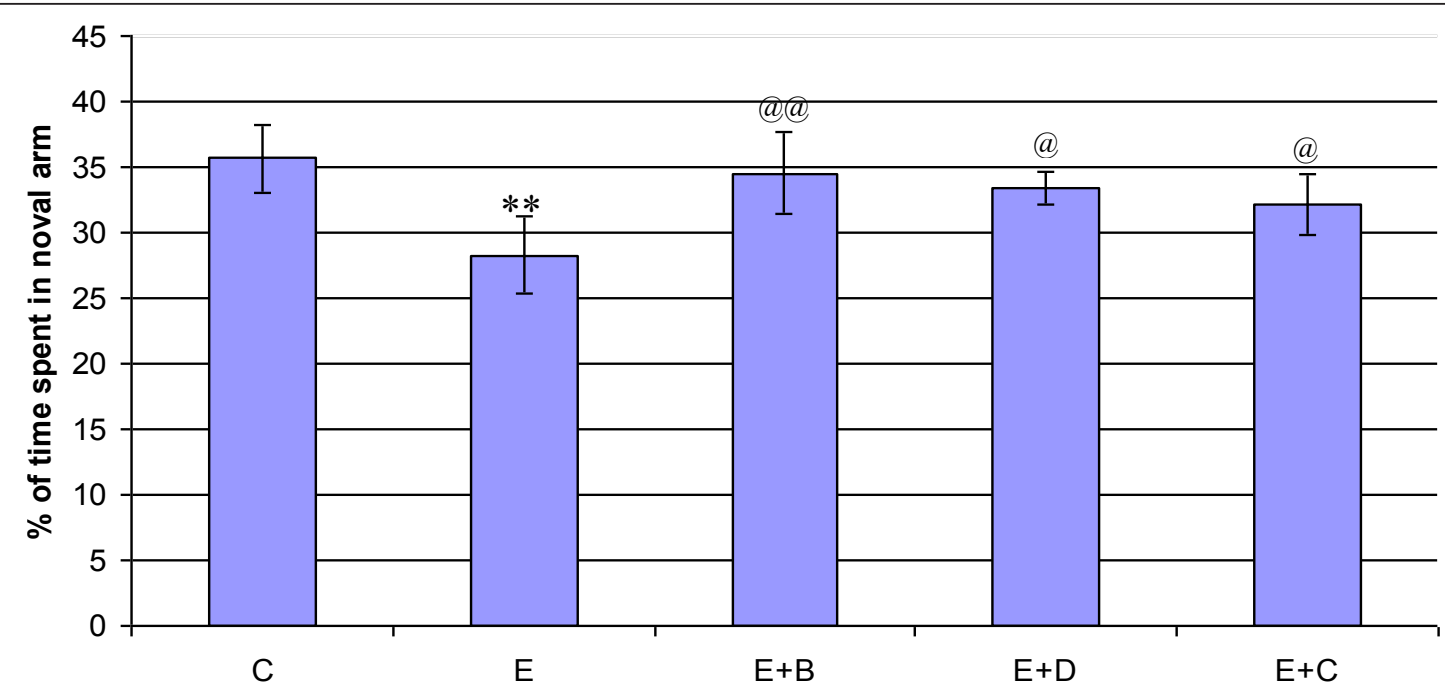

Figure 9 Representative graph showing Y maze performance of control and experimental rats. Epileptic rats showed less exploratory behavior compared to control. C- Control, E- Epileptic, E+B- Epileptic + Bacopa monnieri, E+D- Epileptic + Bacoside-A, E+C- Epileptic + carbamazepine treated rats. ${ }^{* *} p<0.01$ when compared to control, ${ }^{@} p<0.01$ and ${ }^{@} p<0.05$ when compared to epileptic group.

GABA mediated inhibitory postsynaptic potential, whereas $\mathrm{GABA}_{B}$ binding influences the late portion. $\mathrm{GABA}_{\mathrm{A}}$ receptor activation in neurons induced a complex physiological response, namely the activation of a $\mathrm{Cl}^{-}$conductance in concert with a blockade of the resting $\mathrm{K}^{+}$outward conductance results in hyperpolarisation. Both responses were mediated by the activation of $\mathrm{GABA}_{\mathrm{A}}$ receptors, since they were both mimicked by the $\mathrm{GABA}_{\mathrm{A}}$ receptor agonist muscimol and antagonized by picrotoxin and bicuculline [2]. Reductions of GABA mediated inhibition and decreased activity of GAD has been reported in studies of human epileptic brain tissue. Impairment of GABA functions produces seizures, whereas enhancement results in an anticonvulsant effect $[31,32]$. Support for a chronic loss of GABAergic function in epileptogenic human cortex has been based on biochemical assays of tissue resected for relief of focal seizure $[33,34]$. It is reported that in both epileptic and
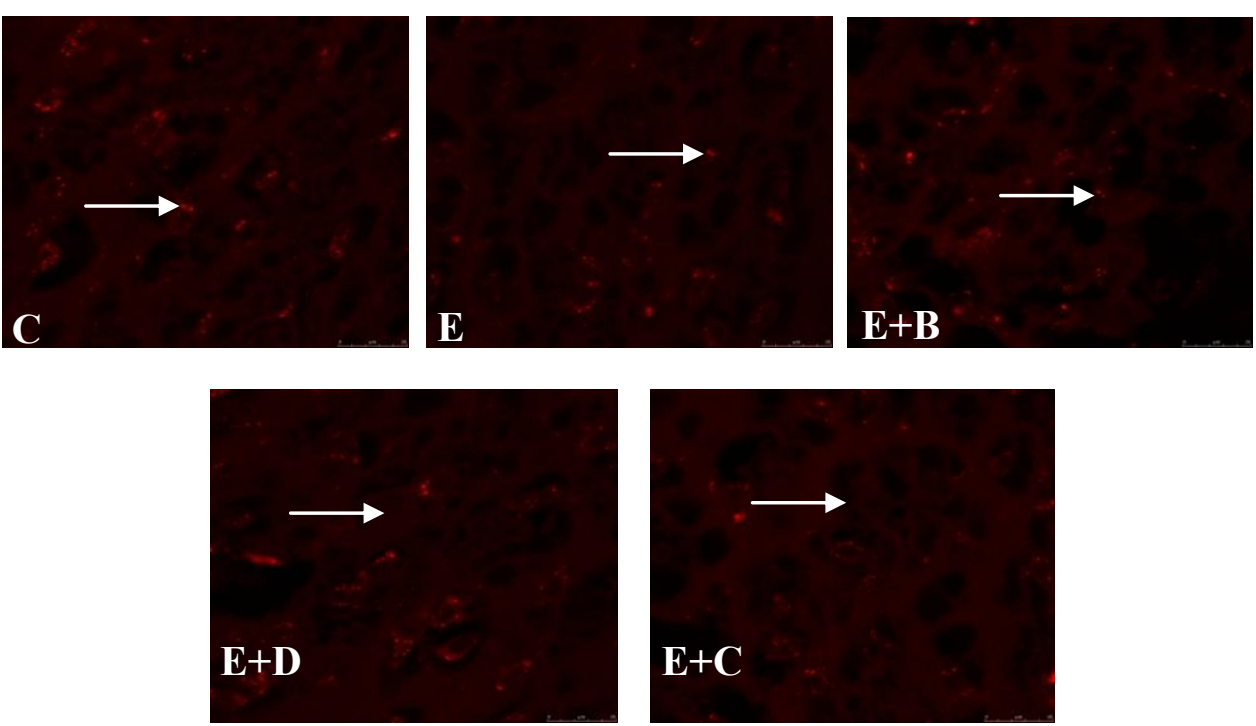

Figure $10 \mathrm{GABA}_{\mathrm{A} \alpha 1}$ receptor subunit antibody staining in the cerebral cortex of Control. and experimental rats. C- Control, E- Epileptic, E + B- Epileptic + Bacopa monnieri, E+D- Epileptic + Bacoside-A, E+C- Epileptic + carbamazepine treated rats. Pixel intensity of experimental rats were C-103465 $\pm 3043, E-76456 \pm 1593^{* *}, E+B-95835^{@ @ ~} \pm 2935, E+D-90564 \pm 2553^{@ @}, E+C-87593 \pm 1093^{@ @}$. () Indicating the GABA ${ }_{A \alpha 1}$ receptor subunit. ${ }^{* *} p<0.01$ when compared to control, ${ }^{@} p<0.01$ when compared to epileptic group. 
histologically damaged cortex, there are significant decreases in GAD and GABA binding [33]. We observed a significant decrease in the $B_{\max }$ of GABA receptors in the cerebral cortex of epileptic rats compared to control GABA receptors and GAD gene expression patterns were similar to the receptor binding studies. Treatment with Bacopa monnieri and Bacoside-A reversed the receptor alterations in $B_{\max }$ and gene expression to near control. Previous studies from our lab showed that Bacopa monnieri treatment to epileptic rats reduced the number of seizures per hour which is suggestive of its anticonvulsant property [35]. GAD plays a very important role in maintaining excitatory inhibitory balance of the central nervous system [36]. Analysis of GAD activity was used as a marker of over all GABAergic activity and was found to be lower in epileptic mice. The enzymatic activity of GAD is the rate limiting step in the production of GABA and GAD serve as a marker of inhibitory neurons. Moreover, preliminary findings indicate that the decrease in GABA is associated with reduced GABA synthesis rather than increased degradation [37]. In order to provide a direct anatomic analysis of GABAergic neurons and terminals in experimental epilepsy, it is demonstrated a significant decrease in immunocytochemically labeled GAD-positive neurons and puncta in and adjacent to an alumina-damaged epileptic focus in monkey motor cortex [38-40].

There are seizure-dependent increases in CRE-binding activities in various brain regions of the mice [41]. Our study showed that CREB mRNA was significantly decreasing in the cerebral cortex of the epileptic rats. Increased expression of total CREB and phosphorelated CREB found in the human epileptic hippocampus. This when considered with the observation that CREB mediate transcription from the $\mathrm{GABA}_{\mathrm{B}}$ Receptor1b $\left(\mathrm{GABA}_{\mathrm{B}} \mathrm{R} 1_{\mathrm{b}}\right)$ and $\mathrm{GABA}_{\mathrm{B}} \mathrm{R} 1_{\mathrm{b}}$ promoters [42]; epileptic rats exhibit elevated levels of GABA B Receptor 2 $\left(G_{A B A} R s\right)$ subunit mRNAs and $G_{A B A}$ Rs antagonist inhibit CREB-DNA binding activity at dose that inhibit seizure behaviour, point to a novel feed back mechanism to $\mathrm{GABA}_{\mathrm{B}}$ receptor in the generation and propagation of seizure.

The incidence of psychiatric diseases in epileptics is significantly higher than in the general population [43-46]. Depressive and anxiety disorders are the most common psychiatric diseases in this patient group. Recent studies employing magnetic resonance spectroscopy (MRS) suggest that unipolar depression is associated with reductions in cortical GABA levels $[47,48]$. Antidepressant and mood-stabilizing treatments also appear to raise cortical GABA levels and to ameliorate GABA deficits in patients with mood disorders [49]. Anxiety disorders have long been associated with disturbances of GABA function because of the ability of the benzodiazepine anxiolytics to facilitate brain GABA neurotransmission [50]. Interestingly, as with plasma studies MRS also reveals lowered concentrations of GABA in occipital cortex in panic disorder [51] and in subjects with alcohol dependence [52]. We used two validated psychopharmacological method Y-maze test to quantify depression-like and anxiety-like behavior induced by the decreased GABA receptors in the cerebral cortex of the epileptic rats. Our study showed decreased exploratory behaviour in epileptic rats and treatment using Bacopa monnieri and bacoside-A brings back the exploratory behaviour to near control. This can be correlated with the decreased GABA receptors in the cerebral cortex of the epileptic rat interaction through 5 -HT pathways. Immobility in rats is considered to be a state of lowed mood or hopelessness which the rodent experience when they are forced to explores in a constrained space from they cannot escape. There are multiple interactions between central GABA and 5-HT pathways, and some of these interactions provide a theoretical framework in which changes in cortical GABA function can lead to some aspects of disrupted 5-HT function seen in depressed patients $[53,54]$. In addition, interactions between $5-\mathrm{HT}$ and GABA offer a route by which $5-\mathrm{HT}$ targeted treatments might alter GABA function to bring about their therapeutic effect [55]. Nigel et al., [56] have suggested shared neurobiological processes leading both to seizures and to behavioral, emotional and cognitive disturbance which could possibly explain the how Bacopa monnieri is effective as an anti-convulsant and an anti-depressant. Carbamzepine treatment to epileptic rats also showed a similar effect.

Cerebral cortex plays a key role in memory, attention, perceptual awareness, thought, language, mood and consciousness. Epileptic patients are often suffering from memory and cognitive problems [57-59]. Preliminary studies established that the treatment with crude extract and with the alcoholic extract of Bacopa monnieri plant [60] enhanced learning ability in rats. The radial arm maze experiment was conducted to study the neurobiological mechanisms that underlie spatial learning and memory functions in experimental. Radial arm maze is a tool to examine the neural systems that are involved in memory, and the influence of pharmacological compounds on memory [61]. Radial arm maze experiment demonstrated the impairment in spatial learning and memory in the model studied. The administration of a crude extract of Bacopa monnieri to epileptic rats decreased the trial to attain the criterion performance in the radial arm maze to control levels. These results confirmed the memory enhancing property of Bacopa monnieri in epileptic rats. It is also reported to facilitate the acquisition, consolidation, retention and recall of learned tasks [62] and improve the speed at which visual 
information is processed. Bacopa monnieri extracts and isolated bacosides have been extensively investigated in several studies for their neuropharmacological effects and a number of reports are available confirming their neuroprotective action [35].

\section{Conclusion}

Our experimental results support that decreased GABA receptors and GAD activity in the cerebral cortex comprise an important role in seizure initiation and mood disorders associated with epilepsy. We conclude from our studies that Bacopa monnieri and Bacoside-A treatment potentiates a therapeutic effect by reversing the alterations in general $\mathrm{GABA}, \mathrm{GABA}_{\mathrm{A}}, \mathrm{GABA}_{\mathrm{B}}$ receptor binding, $G_{A B A}$ receptor subunits, GAD and CREB gene expression that occur during epilepsy, resulting an increased GABA mediated inhibition in the over stimulated cerebral cortex neurons. Bacopa monnieri and Bacoside-A treatment also useful for managing the memory problems and mood disorders associated with the epilepsy. This studies showed the therapeutic significance of Bacopa monnieri, and its active component Bacocide- $\mathrm{A}$ in the management of epilepsy, associated mood disorders and memory problems.

\section{Acknowledgements}

This work was supported by research grants from DBT, DST, ICMR, Govt. of India and KSCSTE, Govt. of Kerala to Dr C S Paulose. Jobin Mathew thanks CSIR for JRF.

\section{Author details}

'Department of Zoology, CMS College Kottayam, Kerala-686 001, India. ${ }^{2}$ Molecular Neurobiology and Cell Biology Unit, Centre for Neuroscience, Department of Biotechnology, Cochin University of Science and Technology, Cochin-682 022, Kerala, India.

\section{Authors' contributions}

JM designed the work and carried out the receptor study. SB participated in the gene amplification studies. SAP and PMA participated in the co focal and behavioural studies. All authors read and approved the final manuscript.

\section{Competing interests}

The authors declare that they have no competing interests.

Received: 3 August 2011 Accepted: 24 February 2012

Published: 24 February 2012

\section{References}

1. Gregory C, Mathews MD: The Dual Roles of GABA in Seizures and Epilepsy Generate More Excitement. Epilepsy Curr 2007, 7:28-30.

2. Labrakakis $C$, Müller T, Schmidt K, Kettenmann H: GABA(A) receptor activation triggers a $\mathrm{Cl}$ - conductance increase and a $\mathrm{K}+$ channel blockade in cerebellar granule cells. Neuroscience 1997, 79:177-89.

3. Williamson PD, Engel JJ, Munari C: Anatomic classification of localizationrelated epilepsies.Edited by: Engel JJ Pedley TA. Epilepsy A Comprehensive Textbook. Lippincott-Raven Publishers, Philadelphia; 1997:2405-2416.

4. Cavalheiro EA, Leite JP, Bortolotto ZA, Turski WA, Ikonomidou C, Turski L: Long-term effects of pilocarpine in rats: structural damage of the brain triggers kindling and spontaneous recurrent seizures. Epilepsia 1991, 32:778-782.

5. Fritschy J: Epilepsy, E/l balance and $\mathrm{GABA}_{\mathrm{A}}$ receptor plasticity. Front $\mathrm{Mo} /$ Neurosci 2008, 1:5
6. Sophie F, Robert FA, Allan J: Tobin, Long term increase of glutamate decarboxylase mRNA in a rat model of temporal lobe epilepsy. Neuron 1990, 5:361-371.

7. Ishige K, Ito Y, Fukuda H: Cyclic AMP Responsive Element- and Activator Protein 1 DNA-Binding Activities in Epilepsy Model Mice. Journal of the Pharmaceutical Society of Japan 1999, 119:510-518.

8. Janine L, Steiger SB, David HF, Shelley JR: CAMP Response ElementBinding Protein, Activating Transcription Factor-4, and Upstream Stimulatory Factor Differentially Control Hippocampal $\mathrm{GABA}_{\mathrm{B}} \mathrm{R} 1 \mathrm{a}$ and $\mathrm{GABA}_{B} \mathrm{R} 1 \mathrm{~b}$ Subunit Gene Expression through Alternative Promoters. The Journal of Neuroscience 2004, 24:6115-6126.

9. David SO: The radial arm maze as a tool in behavioral pharmacology. Physiology \& Behavior 1987, 40:793-797.

10. Caterina M, Hernandez HH, Alvin VT: Spontaneously hypertensive rats: further evaluation of age-related memory performance and cholinergic marker expression. J Psychiatry Neurosci 2003, 28:197-209.

11. Murugesan T: Evaluation of psychopharmacological effects of Bacopa monnieri Linn Extract. Phytomedicine 2005, 8:472-476.

12. Rosane BB, Helena MT: Carbamazepine enhances discriminative memory in rat model of epilepsy. Epilepsia 2004, 45:1443-7.

13. Kwan P, Brodie MJ: Neuropsychological effects of epilepsy and antiepileptic drugs. Lancet 2001, 357:216-22.

14. Russo A, Izzo AA, Borrelli F, Renis M, Vanella A: Free radical scavenging capacity and protective effect of Bacopa monniera L. on DNA damage. Phytother Res 2003, 17:46-54.

15. Singh HK, Dhawan BN: Effect of Bacopa monniera extract on avoidance responses in rat. J Ethnopharmacol 1982, 5:205-14.

16. Singh HK, Dhawan BN: Drugs affecting learning and memory. In Lectures in neurobiology. Volume 1. Edited by: Tandon PN, Bijiani V, Wadhwa S. New Delhi:Wiley Eastern; 1992:189-207.

17. Reas SK, Amee K, Paulose CS: Glutamate receptor gene expression and binding studies in pilocarpine induced epileptic rat: neuroprotective role of Bacopa monnieri extract. Epilep Behav 2008, 12:54-60.

18. Paulose CS, Chathu F, Khan RS, Krishnakumar A: Neuroprotective role of Bacopa monnieri extract in epilepsy and effect of glucose supplementation during hypoxia: glutamate receptor gene expression. Neurochem Res 2008, 33:1663-1671.

19. Krishnakumar A, Nandhu MS, Paulose CS: Upregulation of $5-\mathrm{HT}_{2 \mathrm{C}}$ receptors in hippocampus of pilocarpine-induced epileptic rats: Antagonism by Bacopa monnieri . Epilepsy and behavior 2009, 16:225-230.

20. Racine RJ: Modification of seizure activity by electrical stimulation. After discharge threshold. Electroencephalogr Clin Neurophysiol 1972, 32:269-79.

21. Lowry OH, Roserbbrough N, Farr AL, Randall RJ: Protein measurement with Folin phenol reagent. J Biol Chem 1951, 193:265-275.

22. Kurioka S, Toshiaki K, Makoto M: Effect of Sodim and Bicarbonate lons on GABA Receptor binding in synaptic membrane of rat brain. J Neurochem 1981, 37:418-421.

23. Scatchard G: The attractions of proteins for small molecules and ions. Ann NY Acad Sci 1949, 51:660-672.

24. Ma MX, Chen YM, He J, Zeng T: Effects of morphine and its withdrawal on Y-maze spatial recognition memory in mice. Neuroscience 2007, 147:1059-1065.

25. Akwa Y, Ladurelle N, Covey DF, Baulieu EE: The synthetic enantiomer of pregnenolone sulfate is very active on memory in rats and mice, even more so than its physiological neurosteroid counterpart: distinct mechanisms? Proceedings of the National Academy of Sciences of the United States of America 2001, 98:14033-14037.

26. Chen G, Pan B, Hawver DB, Wright CB, Potter WZ, Manji HK: Attenuation of cyclic AMP production by carbamazepine. Neurochem 1996, 67:2079-86.

27. Engel JJ, Pedley R: Epilepsy -A Comprehensive Textbook.Edited by: Engel JJ, Pedley TA. Lippincott-Raven Publishers; Philadelphia; 1997:1-10.

28. Jin H, Wu H, Osterhaus G, Wei J, Davis K, Sha D, Floor E, Hsu CC, Kopke RD, Wu JY: Demonstration of functional coupling between $\gamma$-aminobutyric acid (GABA) synthesis and vesicular GABA transport into synaptic vesicles. Proc Natl Acad Sci 2003, 100:4293-4298.

29. Joseph J, Niggemann B, Zaenker KS, Entschladen F: The neurotransmitter $\gamma$-aminobutyric acid is an inhibitory regulator for the migration of SW 480 colon carcinoma cells. Cancer research 2002, 22:6467-6469.

30. Smart TG: Regulation of excitatory and inhibitory neurotransmitter-gated ion channels by protein phosphorylation. Curr Opin Neurobiol 1997, 3:358-67. 
31. Schulz DW, Macdonald RL: Barbiturate enhancement of GABA-mediated inhibition and activation of chloride ion conductance: correlation with anticonvulsant and anesthetic actions. Brain Res 1981, 23:177-88.

32. MacDonald RL, Barker JL: Enhancement of GABA-mediated postsynaptic inhibition in cultured mammalian spinal cord neurons: a common mode of anticonvulsant action. Brain Res 1979, 167:323-36.

33. Lloyd KG, Munari C, Bossi L, Stoeffels C, Talairach J, Morselli PL: Biochemica evidence for the alterations of GABA- mediated synaptic transmission in pathological brain tissue (stereo EEG or morphological definition) from epileptic patients. In Neuro- transmitters, Seizures, and Epilepsy. Edited by: Morselli PL. Raven press; 1981:325-338.

34. Lloyd KG, Bossi L, Morselli PL: GABA hypothesis of human epilepsy: Neurochemical evidence from surgically resected identified foci. In Neurotransmitters, Seizures, and Epilepsy II. Edited by: Fariello RG. Raven press; 1984:285-293.

35. Reas SK, Amee K, Paulose CS: Decreased glutamate receptor binding and NMDA R1 gene expression in the hippocampus of pilocarpine induced epileptic rats: neuroprotective role of Bacopa monnieri extract. Epilepsy and Behavior 2008, 12:54-60.

36. Quan L, Meili G, Chang BS, Lowenstein DH: Epilepsy. N Engl J Med 2003, 349:1257-1266.

37. Mason GF, Sanacora G, Hundal R, Petersen K, Shulman G, Graaf R, Rothman D: Preliminary evidence of reduced cortical GABA synthesis rate in major depression. Society for Neuroscience Abstracts 2001, 27:142-6.

38. Ribak $C E$, Harris $A B$, Vaughn JE, Roberts E: Inhibitory GABAergic nerve terminals decrease at sites of focal epilepsy. Science 1979, 205:211-214.

39. Ribak CE, Hunt CA, Bakay RA, Oertel WH: A decrease in the number of GABAergic somata is associated with the preferential loss of GABAergic terminals at epileptic foci. Brain Res 1986, 363:78-90.

40. Ribak CE, Harris AB, Vauahn JE, Roberts E: Immunocytochemical changes in cortical GABA neurons in a monkey model of epilepsy. In Neurotransmitters, Seizures, and Epilepsy. Edited by: Morselli PL. Raven press; 1981:11-21.

41. Ishige $\mathrm{K}$, Ito $\mathrm{Y}$, Fukuda $\mathrm{H}$ : Cyclic AMP Responsive Element- and Activator Protein 1 DNA-Binding Activities in Epilepsy Model Mice. Journal of the Pharmaceutical Society of Japan 1999, 119:510-518.

42. Janine L, Steiger SB, David HF, Shelley JR: cAMP Response ElementBinding Protein, Activating Transcription Factor-4, and Upstream Stimulatory Factor Differentially Control Hippocampal $G_{A B A} R 1 a$ and $G_{A B A_{B}} R 1 b$ Subunit Gene Expression through Alternative Promoters. The Journal of Neuroscience 2004, 24:6115-6126.

43. Kanner AM, Soto A: Ictal recordings in postictal psychosis and postictal depression. Neurology 1998, 50:390-397.

44. Mendez MF, Cummings JL, Benson DF: Depression in epilepsy: significance and phenomenology. Arch Neurol 1986, 43:766-770.

45. Mendez MF, Doss RC, Taylor JL: Depression in epilepsy: relationship to seizures and anticonvulsant therapy. J Nerv Ment Dis 1993, 181:444-447.

46. Robertson MM: Ictal and interictal depression in patients with epilepsy, in Aspects of Epilepsy and Psychiatry.Edited by: Trimble MR. John Wiley 1986:213-333.

47. Sanacora G, Mason GF, Rothman DL, Behar KL, Hyder F, OA Berman RM: Reduced cortical gamma-aminobutyric acid levels in depressed patients determined by proton magnetic resonance spectroscopy. Archives of General Psychiatry 1999, 56:1043-1047.

48. Sanacora G, Mason GF, Krystal JH: Impairment of GABAergic transmission in depression: new insights from neuroimaging studies. Critical Reviews in Neurobiology 2000, 14:23-45.

49. Krystal JH, Sanacora G, Blumberg H, Anand A, Charney DS, Marek G, Epperson CN: Glutamate and GABA systems as targets for novel antidepressant and mood-stabilizing treatments. Molecular Psychiatry 2002, 7:71-80

50. Honig A, Bartlett JR, Bouras N, Bridges PK: Amino acid levels in depression: a preliminary investigation. Journal of Psychiatric Research 1988, 22:159-164.

51. Goddard AW, Mason GF, Almai A, Rothman DL, Behar KL, Petroff OA, Charney DS: Reductions in occipital cortex GABA levels in panic disorder detected with $1 \mathrm{H}$-magnetic resonance spectroscopy. Archives of General Psychiatry 2001, 58:556-561.

52. Behar KL, Rothman DL, Petersen KF, Hooten M, Delaney R, Petroff OA, Shulman Gl: Preliminary evidence of low cortical GABA levels in localized
1H-MR spectra of alcohol-dependent and hepatic encephalopathy patients. American Journal of Psychiatry 1999, 156:952-954.

53. Gellman RL, Aghajanian GK: Pyramidal cells in piriform cortex receive a convergence of inputs from monoamine activated GABAergic interneurons. Brain Research 1993, 600:63-73.

54. Freund TF, Gulyas Al, Acsady L, Gorcs T, Toth K: Serotonergic control of the hippocampus via local inhibitory interneurons. Proceedings of the National Academy of Sciences of the United States of America 1990, 87:8501-8505.

55. Bhagwagar Z, Whale R, Cowen PJ: State and trait abnormalities in serotonin function in major depression. British Journal of Psychiatry 2002, 180:24-28

56. Nigel JC, Salzberg MR, Gaurav K, Abbie C, Margaret JM, Terence JO: Elevated anxiety and depressive-like behavior in a rat model of genetic generalized epilepsy suggesting common causation. Experimen Neurol 2008, 209:254-260

57. Rausch R, Kraemer S, Pietras CJ, Le M, Vickrey BG, Passaro EA: Early and late cognitive changes following temporal lobe surgery for epilepsy. Neurology 2003, 60:951-959.

58. Blake RV, Wroe SJ, Breen EK, McCarthy RA: Accelerated forgetting in patients with epilepsy Evidence for an impairment in memory consolidation. Brain 2000, 123:472-483.

59. Butler $C R$, Zeman $A Z$ : Recent insights into the impairment of memory in epilepsy: transient epileptic amnesia, accelerated long-term forgetting and remote memory impairment. Brain 2008, 131:243-263.

60. Singh HK, Dhawan BN: Effect of Bacopa monnieri extract on avoidance responses in rat. J Ethnopharmacol 1982, 5:205-214.

61. Leung LS, Boon KA, Kaibara T, Innis NK: Radial maze per-formance following hippocampal kindling. Behav Brain Res 1990, 40:119-129.

62. Roodenrys S, Booth D Bulzomi S, Phipps A, Micallef C, Smoker J: Chronic effects of Brahmi (Bacopa monnieri) on human memory. Neuropsychopharmacology 2002, 27:279-81.

\section{doi:10.1186/1423-0127-19-25}

Cite this article as: Mathew et al:: Decreased GABA receptor in the cerebral cortex of epileptic rats: effect of Bacopa monnieri and Bacoside-A. Journal of Biomedical Science 2012 19:25.

\section{Submit your next manuscript to BioMed Central and take full advantage of:}

- Convenient online submission

- Thorough peer review

- No space constraints or color figure charges

- Immediate publication on acceptance

- Inclusion in PubMed, CAS, Scopus and Google Scholar

- Research which is freely available for redistribution

Submit your manuscript at www.biomedcentral.com/submit
C Biomed Central 